\title{
Corporate Social Responsibility Information Disclosure Research
}

\author{
Juan Wang * \\ School of Economics and Management \\ Guangxi University of Science and Technology \\ Liuzhou, China
}

\author{
Liping Lin \\ School of Economics and Management \\ Guangxi University of Science and Technology \\ Liuzhou, China
}

\begin{abstract}
Since the 1970s, as a long-term concern of the academic and practical circles, research on corporate social responsibility has continued to develop in depth, and a large number of research results have been obtained. Corporate social responsibility can balance the interests of stakeholder groups. The special relationship between the company and the stakeholders will affect the motivation, influencing factors and economic consequences of the company's disclosure of social responsibility information. This paper combs the literature on the motivation, influencing factors, and economic consequences of social responsibility information disclosure, and proposes new ideas for corporate social responsibility information disclosure research based on motivation-influencing factors-economic consequences. The study found that companies will disclose social responsibility for the purpose of profitability, financing needs and agency costs, and will ultimately affect the company's capital cost and investor decisions. On this basis, future research prospects for corporate social responsibility information disclosure are proposed.
\end{abstract}

Keywords-corporate social responsibility; disclosure motivation; influencing factors; economic consequences

\section{INTRODUCTION}

With the rapid economic growth, the problems of corporate society and the environment have become increasingly prominent. The risk of product safety and quality, the loss of employee rights, the waste of resources, environmental pollution, and other corporate non-compliance with social responsibility have repeatedly become hot issues in society. As China's economic development enters a new normal, enterprise development gradually moves from the speed of development to the quality of development. More and more enterprises are beginning to pursue the maximization of the comprehensive value of economy, society and environment. By fulfilling their responsibilities to various stakeholders, enterprises can promote the organic unification of their economic, social and environmental values and contribute to the sustainable development of enterprises. In 2006, "Responsible for Social Responsibility" was officially written into our company law. In 2008, the China Securities Regulatory Commission, the Shanghai Stock Exchange and the Shenzhen Stock Exchange jointly issued a notice requesting listed companies to disclose corporate social responsibility reports. Therefore, regardless of the development of the company itself, or the expectations and requirements of stakeholders, the company's active commitment to the social responsibility of all stakeholders is a link that enterprises can't ignore for sustainable development.

The concept of "corporate social responsibility" can be traced back to 1924. The British scholar Sheldon made a preliminary definition of "corporate social responsibility" in the book "Management Philosophy". He believed that in the course of business, the company can take into account the needs of various groups of people inside and outside the organization, and has already reflected the social responsibility of the company. Thirty years later, the formal definition of corporate social responsibility was proposed by American scholar Bowen (1953). In his book "Social Responsibility of Merchants", Bowen pointed out the social responsibility of businessmen is the formulation of the execution of business decisions. The whole process should consider the goals and values expected by society, and further suggest that the decision-making of enterprises based on the recognition of social goals may lead to more economic and social benefits. This opened the prelude to modern research on social responsibility. Since the 1970s, people's calls for corporate social responsibility have gradually increased, and some countries and regions have begun to respond to such calls and translate social responsibility into practical actions. More than ten years later, corporate social responsibility reports have gradually been adopted by many large enterprises. The wide application of social responsibility standards (ISO26000) and social ethics standards (SA8000) on a global scale also provides a model for corporate social responsibility disclosure.

As a long-term concern of the practical and academic circles, corporate social responsibility has been continuously developed in-depth and has achieved a lot of research results. Based on the combing of related literature, this paper summarizes the relevant research results around the motives, influencing factors and economic consequences of corporate social responsibility information disclosure. Furthermore, it puts forward the possible research directions and ideas of corporate social responsibility issues in the future.

\section{THE MOTIVATION FOR DISCLOSURE OF CORPORATE SOCIAL RESPONSIBILITY INFORMATION}

Motivation refers to the internal causes that directly drive individuals to conduct their activities. Motivation drives individuals to engage in certain behaviors, motivate individuals, and direct individual behavior to act toward specific goals. As a 
transmission theory, and show investors that they are responsible social citizens and meet corporate financing needs.

According to the theory of signal transmission, the more information a company discloses to the outside, the weaker information asymmetry between the company and its investors. It will help investors make more rational decisions. According to Fama and Miller (1972), external financing can compensate for the lack of cash flow in corporate profitability, thereby maximizing value and the need for corporate investment activities. Therefore, companies will voluntarily disclose social responsibility information for the sake of financing needs. Zhai Huayun(2010) took the manufacturing enterprises as the research object and found that with the high quality of social responsibility information, the high external financing demand is[2]. It can be seen that one of the motivations for companies to disclose social responsibility information is achieving corporate financing needs.

information to configure resources, and then make the market reach Pareto optimal. However, with the development of society, people gradually realize the existence of information asymmetry. In the capital market, the difference in information mastery between company managers and other stakeholders is typical information asymmetry. Company managers are responsible for the company's operations and are able to grasp all the information about the company's operations, while other internal and external stakeholders only use the information disclosed by the managers to speculate on the company's real situation.

Vaani Anand (2002), Tiago Melo and Jose Ignacio Glan (2011) believed that corporate social responsibility can enhance corporate reputation[1]. Schwaiger (2004) believed that reputation is a scarce resource for enterprises, and it is not imitative. So it can form a strong competitive force. The existence of the theory of information asymmetry allows the company's stakeholders other than management to grasp part of the company's information. Therefore, companies with good performance will voluntarily disclose more information to distinguish them from other companies with average performance and enhance their corporate image by showing themselves that they are good social citizens. Thus gain more favor from investors. Stimulate the company's stock price rise and improve the company's profitability. Therefore, one of the motivations for companies to disclose social responsibility information is improving the company's profitability.

\section{B. Motivating financing needs}

Nobel Prize-winning economist Michael Spencer introduced the theory of signal transmission into economics research. He found that in the market, individuals who have sufficient information to transmit information to individuals who have a disadvantage in information in order to avoid problems related to adverse selection. In order to obtain more limited resources in the capital market, companies with good corporate performance will transmit this information to the outside world through information disclosure, thereby attracting investors and achieving the financing goals of the company. At the same time, due to the reduction of transaction costs, the financing cost of enterprises will also decrease. Therefore, enterprises will actively disclose social responsibility information after recognizing the role of signal

\section{Motivating reducing agency cost}

With the rapid development of social productivity and the gradual expansion of the scale of enterprises, there has been a situation in which enterprise ownership and management rights are separated. The existence of the agency relationship makes it unnecessary for the business owner to personally take charge of the company's operation and management, which also makes it impossible for the owner to fully grasp the various information of the enterprise. Therefore, business owners will ask managers to disclose more information to them. In order to meet the expectations of the profit maximization of the business owner, the manager will disclose the social responsibility information as much as possible, show the owner that he is a qualified agent, and obtain higher compensation. The view of the principal-agent theory is that the information asymmetry between the principal and the agent leads to the generation of agency costs. The agent seeks to maximize self-interest, and the principal seeks to maximize the profit of the enterprise.

Forker(1992) pointed out that when the duties of the chairman and general manager are one-person, there is a negative impact on the disclosure of social responsibility information. When the roles of chairman and general manager are separated, in order to reduce agency costs, the general manager will voluntarily disclose more social responsibility information. It can be seen that reducing agency costs is also one of the motivations for companies to disclose social responsibility information.

\section{FACTORS AFFECTING CORPORATE SOCIAL RESPONSIBILITY INFORMATION DISCLOSURE}

With regard to the influencing factors of corporate social responsibility information disclosure, the existing empirical research mainly analyzes from two angles, one is the external environment level of the enterprise, and the other is the internal driving force of the enterprise. The external environment of the enterprise includes the national macro environment and stakeholders. The internal driving force of the enterprise includes establishing the corporate image and strategic management motivation. 
with stakeholders. It can be seen that reputation does affect corporate social responsibility information disclosure. Lian Chunhui et al. (2016) concluded that reputation positively affects information disclosure [3]. Shen Hongtao et al. (2011) found that social responsibility performance will also promote the improvement of corporate reputation[4]. It can be seen that there is an interactive relationship between reputation and social responsibility information disclosure. In order to establish a good corporate image for the outside world, enterprises will actively disclose social responsibility information.

Beginning in the late 1990s, some management scientists combined corporate strategic management theory with corporate social responsibility issues. Porter et al. (2006), a famous competitive strategist at Harvard University, believed that companies can gain a competitive advantage by taking social responsibility. Therefore, the motivation of a company to conduct strategic management may affect the disclosure of its social responsibility information.

\section{THE ECONOMIC RESULTS OF CORPORATE SOCIAL RESPONSIBILITY INFORMATION DISCLOSURE}

With regard to the study of the economic consequences of corporate social responsibility information disclosure, the existing empirical research mainly focuses on two capital market effects, the impact on the company's capital cost and investor decision-making value.

stakeholders. Ultmann (1985) proposed that the role, content, and evaluation of social responsibility reports should be analyzed in the context of political interests and conflicts. By applying the theory of stakeholders to the prediction and interpretation of corporate social responsibility activities and their information disclosure behaviors, a comprehensive and complete social responsibility theory framework model is constructed. The framework includes two important dimensions: the greater the power of stakeholders, the more important they are to the disclosure of corporate social responsibility information; the more positive the strategic situation of the enterprise, the more stakeholders expect the company to disclose information about its social responsibility. Under this theoretical framework, the purpose of corporate social responsibility information disclosure is alleviating conflicts with interest groups. For the motivation of legal litigation costs, Patten (1991) and Gray \& Vint (1995) found that when the company's industry faced environmental pollution, legal proceedings and other difficulties, it would disclose more social responsibility information.

\section{B. The intrinsic driving force of the enterprise}

Basu \& Palazx (2008) believed that corporate social responsibility is not only the result of external pressure but also the embodiment of the inherent nature of the organization. Kreps et al. (1982) established a standard reputation model in economics, arguing that the level of corporate reputation affects consumers' perceptions of the business and the decisions consumers' made. If a company's environmental performance is good, its reputation in society will be higher than other companies. Companies with high reputations tend to disclose more social responsibility information to reflect their performance in social performance, and actively communicate

\section{A. The impact on capital costs}

A study by foreign scholar Anderson \& Frankle (1980) showed that disclosure of social responsibility information can affect stock prices and transfer market signals. Guidry and Patten (2010) found that companies that publish high-quality sustainability reports have a positive market response. Conversely, the company's market response to low-quality sustainability reports is negative. Verrecchia (2001) believed that corporate social responsibility information disclosure may play a similar role as financial information disclosure, which reduces information costs by reducing information asymmetry and transaction costs. Domestic scholar Zhao Liangyu (2017) found that there is a negative correlation between the quality of corporate social responsibility information disclosure and the cost of equity financing or debt financing[5]. This effect is more pronounced in non-state-owned enterprises, that is, nonstate-owned enterprises have strong incentives to undertake social responsibilities and disclose social responsibility information.

\section{B. The impact on an investor decision value}

Foreign scholar Dhaliwal et al. (2011; 2012) also studied the reaction of investors in the capital market to the disclosure of corporate social responsibility information. The study found that investors are more willing to choose companies that disclose social responsibility information as investment objects. And society disclosure of liability information can improve analysts' forecast accuracy. Milne \& Patten (2002) examined their responses to corporate disclosure of social responsibility information by issuing questionnaires to investors. The results 
information disclosure, we should continuously broaden the research field, conduct in-depth and detailed analysis in combination with specific regions, systems, markets, and cultural environments, and improve the measurement methods for corporate social responsibility information disclosure. The future direction of social responsibility information disclosure research is forming a consensus conclusion recognized by the public. In terms of influencing factors, the internal mechanism and decision mechanism of corporate social responsibility information disclosure should be deeply analyzed. Further strengthening the driving force and motivation of corporate social responsibility information disclosure. In terms of economic consequences, we should explore the corporate social responsibility information disclosure based on the market environment background. The market effect examines the impact of corporate social responsibility information disclosure on investor behavior, transaction costs, and market information environment.

\section{REFERENCES}

[1] Melo T, Galan J I. Effects of corporate social responsibility on brand value[J]. Journal of Brand Management, 2011, 18(6):423-437.

[2] Qi Huayun. The Impact of External Financing Demand on Corporate Social Responsibility Disclosure under Soft Budget Constraints[J].China Population Resources and Environment,2010,20(9):107-112.(In Chinese)

[3] Lian Chunhui. Research on Corporate Social Responsibility Information, Corporate Reputation, and Stakeholder Behavior Intent [D]. Nanjing University, 2016. (In Chinese)

[4] Shen Hongtao, Wang Liyan, Wan Tuo. Can Social Responsibility Report and Assurance Pass Effective Signals? - Analysis Based on Enterprise Reputation Theory[J].Auditing Research,2011,(04):87-93.(In Chinese)

[5] Zhao Liangyu, Yan Xinyi, Liu Fenfen. The Impact of Social Responsibility Information Disclosure on Corporate Finance Costs Based on Empirical Evidence of Listed Companies in China[J]. Journal of Guizhou University of Finance and Economics, 2017(6): 40-52. (In Chinese)

[6] Zhu Song. Corporate Social Responsibility, Market Evaluation and Earnings Information Content [J]. Accounting Research, 2011 (11): 27$34+$ 92.(In Chinese) foreign scholars' research on corporate social responsibility is gradually deepening and the research field is broadening, laying a good foundation for subsequent research. Looking forward to the future research on social responsibility 